\title{
Indictment and its constituent components
}

\author{
Amantia LEVANAJ \\ $\mathrm{PhD}$ candidate \\ University of Tirana, Faculty of Law \\ Email: amantialevanaj@gmail.com
}

DOI:10.5901/mjss.2014.v5n19p93

\begin{abstract}
This paper focuses primarily on the treatment of the indictment and its constituent components, considering it as a tool for the protection and realization of individual rights. Indictment Institute discloses an even more special interest. Indictment Institute discloses an even more special interest on various studies and treatments. In specific periods in the development of society, starting from the Roman period, in which it originated and then followed by the period Ottoman, in which this institute was obviously improving to the present days, analyzing the issues of the concept of the claim, its types, interest to act in judgment, filing a petition as well as its constituent elements. Through this paper I clearly highlight that the indictment institute is considered as a one of the oldest institutions in the development of society. The focus of any democratic state is precisely the protection of human rights and fundamental freedoms, whether pecuniary or non-pecuniary and exactly for this reason serves the investment of the courts, through the institution of the indictment to seek the protection of these rights in case of their breach. The civil lawsuit along with its constituent elements is a legal institution which ensures the protection of individual rights of persons from any violation or violations that may occur as a result of the actions of third parties. The study includes treatment of legal doctrine, classifying the claim in terms of procedural and substantive concept. In material terms, the claim implies that kind of legal power that a person has to seek the realization of a civil right against another person regardless or against his will, while the procedural concept has the legal power to invest the court for recognition or restoration of a right denied or violated by another person, ie civil lawsuit on procedural sense is a means of protection of a right through the court.
\end{abstract}

Keywords: Lawsuit, procedural capacity, claim petition, the parties, the legal doctrine.

\section{INTRODUCTION}

Protection of human rights and fundamental freedoms, which includes those with pecuniary and non- pecuniary character, continues to be one of the main focuses of any democratic state. Various historical records attest to the protection of these rights since the time of primitive societies regardless of their organizational form.

In different historical periods lawsuit is labeled as a mean for the protection and realization of subjective rights. For this reason, this institute is always interesting for further studies and treatments. On this topic I intend to treat also procedural protective means of the respondent, to provide the meaning of a civil judicial process, on one side of which lies the petitioner with his requests, and on the other side of lies the respondent with his objections against petitioner. For the purpose of this topic, the structure of the paper contains four chapters starting with a historical overview of the lawsuit wherein the lawsuit is treated since the Roman period in which there is its origins, followed later by the Ottoman period where institutes of lawsuit, where the institute of the lawsuit by the course of time was being improved since the time it was created and by completing this historical overview with the current state of nowadays about this institute followed by the meaning and types of lawsuit, the elements of the lawsuit, interest in acting to judgment, contents of filing a lawsuit, the procedural means of protecting the respondent, impeachments and counterclaim.

\section{HISTORICAL OVERVIEW ON INDICTMENT INSTITUTE}

The lawsuit is one of the oldest institutes and one of the main tools for the protection and restoration of the subjective right. "Among primitive peoples, the disputes were resolved through the use of violence. Later, during a second phase, the magical-religious beliefs impose a forced submission to the rites and ceremonies in duels or in the judgments of the Lord. 
These rites of disputes character controlled by priests presented the will of gods in favor of him who had performed these rites in the most perfect way.".1

In subsequent periods, the disagreement began to be resolved through vigilantism. Subsequently, the use of violence began to be limited due to a decree issued by Marcus Aurelius. "This decree ruled that creditors should always be addressed to the judges for their claims against debtors" because if they intervene on the property of debtors, without the permission of anyone, lose their their right to credit". 2

In the post-classical law was necessary to address at legal bodies for recognition or sanctioning rights.

Recognition or sanctioning rights was required by the legal bodies through action, or otherwise claimant. In the Roman law, "Celsus has given this definition," the lawsuit is nothing else than the right to legally ask what someone owes you. "'Since that time, the lawsuit is considered as a plaintiff's legal action in order to ensure a favorable final decision for him".3

The right to lawsuit was closely associated with interest, because just having an interest; they can set in motion a certain process.

" The active legitimacy consisted in the right availability of filing suit in your favor, while the passive one, on being sued as a result of creating concerns in the exercise of real rights or due to failure to meet the obligations." 4

To present petition before the magistrate, to summon at the trial also the person against whom the petition addressed to the defendant. In the process, the magistrate may accept the lawsuit or to reject it.

"When the plaintiff and the defendant were presented to the magistrate, the plaintiff with words or solemn gestures had to submit the lawsuit to the defendant. The defendant may hold different attitudes against it, could accept, could meet with his request, could be silent, could be defended in vanity, even could deny by solemn gestures" 5

Act wherein reflected the content of the objection of the defendant when was sent for trial to the judge called litis contestation.

\section{MEANING OF LAWSUIT AND INTERPRETATION OF ITS TYPES.}

The civil lawsuit is a legal institution that ensures the protection of subjective individual rights of persons from any violation or infringement that may be caused as a result of the actions of third parties. Infringement or violation of the rights of individuals can be performed by private individuals as well as entities of public law and therefore any person affected may exercise the right to sue not only against private individuals but also against democratic and against public persons such as institutions state. The right to address the court by means of a civil lawsuit, is guaranteed also by Article 42 of the Constitution of the Republic of Albania which provides that "any person who alleges that a right has been violated, has the legitimate right to a fair trial and public hearing within a reasonable time by an independent and neutral court appointed by law. ". The courts have a duty to protect against any violation of the legitimate rights and interests of individuals. Protection on civil rights and interest made by the trial or civil proceeding which is propelled by means of a civil lawsuit.

According to Italian Doctrine, "the lawsuit is legal opportunity to put in place the criteria for law enforcement, and every right as possible, is a ideal typical power, so is the opportunity to have legal effects specified (law enforcement)"

"There are still authors who continue to support the thesis that the lawsuit is a subjective right independent of the right material which seeks to gain recognition or sentence. Besides the material right would have also a procedural subjective right which seeks to recognize and respect the right ".6

Such a thesis faces many difficulties, but we can say that "the lawsuit is a possibility, a legal power allowing public institutions and individuals to invest the court to reach the observance of the law. To address the court has an impersonal and objective and permanent character, by which a person can not give up in general and absolutely, except in special

\footnotetext{
1Roman Law.Arta Mandro, p.450.

2 lbid.

3 lbid.

${ }^{4}$ lbid.

5 lbid.

${ }^{6}$ Civil Procedure 24 iem edition.Jean Vincent Serge Guinchard,p.75
} 
cases as may be waiver from a special lawsuit. This legal power is regulated by law in an abstract way. It is attributable to any person.". 1

"The subjective material right aims prestim from the opposing side, while the lawsuit aims to set in motion the court.

The second difference lies in the fact that the subjective right material is addressed to opposing party as can be as private and public character 2, while the lawsuit invests the judicial bodies, asking them a legal protection of its rights, so it is of public character.".3

The lawsuit in material terms has many interpretations, some of which are presented below in order to emphasize its true meaning. "Civil lawsuit in material terms is the legal faculty or power of a person to seek the realization of a civil right against another person, regardless or against his will."18. "Through the lawsuit, the party seeks to realize its own right of the material right against the opposing party or clarifies its legal relations with." 4

The right to lawsuit in material terms is itself subjective right. This subjective right, the person asks to achieve through coercive force of the state, namely through the court.

"The lawsuit in material terms is claiming a right to the material against the defendant by the plaintiff by the court. In material terms lawsuit is the right protected by the court. "Through lawsuit he expects the court to ensure recognition and reinstatement of his right to prejudice the defendant.

Code of Civil Procedure defines the lawsuit in its Article 31 which provides that "The lawsuit is the right of the person who makes the claim, to be heard on the merits of this claim, in order the court to announce based or not."

A approximate definition by section 31 of the Code of Civil Procedure makes the Civil Procedure Code of Italy, when it provides that "Anyone who seeks a right in court, must submit a lawsuit to competent court" 5 . A definition more or less similar to the Albanian legislation provides the French Civil Procedure Code which stipulated that "the lawsuit is the right to the applicant of a claim, to be heard on the merits of this claim in order the court to announce based or not" 6 .

The difference between the lawsuit, the substantive and procedural meaning is that the lawsuit may be declared admissible by the court in procedural terms but can be declared inadmissible in material terms. Article 112 of Civil Code provides that if the plaintiff did not exercise the right to lawsuit within the time allowed by law, then he can not carry on this right by means of coercive force of the state. 7

From the provisions cited above, it comes to the lawsuit in its material sense, which gives the right the subject that has a right to address to state, which through its coercive force to accomplish his right, but entity has the obligation and the right to petition for the implementation of its subjective right to seek within the time prescribed by law, otherwise his right over the limit can not be achieved through the coercive force.

"The lawsuit on procedural sense is the faculty or legal power to ask the court for recognition or restoration of a right denied or violated by another person, which calls regularly before the courts, ie. civil lawsuit in procedural terms is a means of protection right through court".8

Doctrine is defined in the procedural sense lawsuit as "a remedy by which interested persons and those authorized by the law of the court with a request for review and resolution of civil legal disputes and civil rights protection".9

"The lawsuit in the procedural sense is the act by which the plaintiff submits his claims against the defendant". 10

To exercise the right to lawsuit in the procedural sense certain conditions should be met objective and subjective character.

${ }^{1}$ Civil Procedure 24 iem edition.Jean Vincent Serge Guinchard,p.76

2 If the right is addressed against individual or state.

3Manuale di diritto processuale civile Enrico Tullio Liebman,fa .140.

${ }^{4}$ Civil Procedure of the People's Republic of Albania.Alqiviadh Lamani Tirana 1962.p.101

${ }^{5}$ Compared overview of Civil Procedure.. A.Simoni, S.Sadushi,S.Como Tirana 2006. p.111

${ }^{6}$ Codice di Procedure Civile Italiano.article 99

${ }^{7}$ Article 112 of the Civil Code of 1994 provides that "The right of lawsuit which is not filed within the period prescribed by law, can not be extinguished and carried on by the court or other competent authority

${ }^{8}$ Civil Procedure of the People's Republic of Albania..Alqiviadh Lamani Tirana 1962 p.101.

${ }^{9}$ Civil Procedure Law of of the People's Republic of Albania . Stavri Ceco,Ylbere Malindi,Safet Hasani, p 158

${ }^{10} \mathrm{Code}$ of Civil Procedure of the People's Republic of Albania, year 1958. article 45 
Subjective condition is that the person who presented himself to the court and file a petition with the person whose name is submitted the petition to have the legal capacity, because just having eligible persons can enter into legal relations between them. 1 "The objective terms of filing suit, are divided into positive conditions and negative conditions of exercise of the lawsuit."2

Positive conditions that should complement a lawsuit are:

Lawsuit should be filed in the court where the appeal is subject to suit, enters the court jurisdiction. Code of Civil Procedure provides that: "In court jurisdiction includes all civil disputes and other disputes in the codes provided in special laws.". 3

2. Lawsuit which can not be accepted for review for the reason that does not enter under the jurisdiction of the court are those which enter the administrative jurisdiction in the jurisdiction of the arbitral tribunal only on condition that the arbitration agreement to be valid. The claim must be presented in temporal and subject matter jurisdiction of the court, namely "specific court before which the action is filed should be competent to try the case" 4

3. The lawsuit that will not appear in court to be tried first, and not be given a final decision between these same parties, for tënjëjtin and legal reasons for the same object. 5

4. A lawsuit is not accepted to examine whether a lawsuit with a similar object between those same parties and the same legal cause is pending trial 6"Subjective and objective conditions for exercising the right to sue procedural in nature, ie not related to the plaintiff's subjective right material for the right to petition the court in the above manner is just the requirement that it be accepted by the court for consideration and appropriate decision to be given.". 7

Terms of acceptance of the claim, as they $O \varphi$ subjective character and objective character are procedural requirements that must be met to review the lawsuit.

Procedural requirements can be absolute and relative. Absolute requirements are those procedural requirements that must be met in order to continue the normal process. Relative requirements are those procedural requirements which although may not be available in lawsuit again claim review process can continue to normality.. 8

Code of Civil Procedure does not divide the procedural requirements in absolute and relative.

However such a division between those requirements is meant to analyzing claims court can be largely taken on board and request that the court take into consideration only at the request of the parties. Thus the capacity to be party to the proceedings, the jurisdiction of the court, the jurisdiction of the court, be taken into consideration by the court and as such are considered as absolute procedural requirements.

As the relative demand may mention forecast demand for the right to raise the claim, which the court assessed only on the request of the respondent in the form of rebuttals and non Suo moto by the court.. 9

\section{CONSTITUENT COMPONENTS OF THE LAWSUIT}

The elements contained in the lawsuit are listed as follows:

1. legal cause;

${ }^{1}$ Civil Procedure (Lectures) Tirana 2003 Vitore Tusha and Flutura Tafaj p.25

${ }^{2}$ Code of Civil Procedure dated 29.03.1996 art. 451/a "The decision that has become final is binding on the parties, for their heirs, for those who give the right of the parties, the court which rendered the judgment and all courts and other institutions

${ }^{3}$ Article 58 of the Civil Procedure Code provides that "when in the same court or in different courts in the same time examine the dispute between the same parties and the same cause and the same object, decided to dismiss the case of disputes submitted after that first registered with .

${ }^{4}$ Civil Procedure Code, Tirana, article 36/1

${ }^{5}$ Comparative Overview on Civil Procedure. Tr 2006, A.Simoni,S.Sadushi,S.Como p.114

${ }^{6}$ The Civil Procedure (lectures) Tirana 2003 Vitore Tusha and Flutura Tafaj p.25

${ }^{7}$ Code of Civil Procedure dated 29.03.1996 art. 451/a "The decision that has become final is binding on the parties, for their heirs, for those who give the right of the parties, the court which rendered the judgment and all courts and other institutions.

${ }^{8}$ Article 58 of the Civil Procedure Code provides that "when in the same court or in different courts in the same time examine the dispute between the same parties and the same cause and the same object, decided to dismiss the case of disputes submitted after that first registered with

${ }^{9}$ Albanian Civil Procedure Law, Dispenca 1.Tirana 1974. P. 119. 
2. object::

1. Entities (parties).

The legal cause of the lawsuit is the reason for the judicial request and is divided into two elements:

The first element of legal cause is the right. The right is the legal reference, is the legal basis as part of legal cause. Through the law, the plaintiff shows that his request is based on material right and that right is protected by law. Plaintiff pursuant to Section 154 of the Code of Civil Procedure, when presenting his petition to the court must bear right onto which the lawsuit is relied. Because of different practices regards the concept of legal causation and the law. The Supreme Court has unified judicial practices and the decision dated 09.03.2006 No. 9 stated that <Showing of the right on which the petition is relied $>$, in terms of Article 154 of the Code of Civil Procedure, corresponds to subjective right of the plaintiff as part of the "cause of the claim" within the meaning of Article 185 of the Code of Civil Procedure and the determination "of the legal basis of the claim" within the meaning of Article 16/2 of the Code of Civil Procedure.

To achieve a correct conclusion, it is necessary to interpret Article 16 of the Code of Civil Procedure which states that "the Court resolves the dispute in accordance with legal provisions and other applicable rates, which are required to be implemented by it. It makes a precise setting of the facts and actions related to disputes, without regard to the determination that the parties can make. However the court may not change the legal basis of the claim without the request of the parties."

Second element: legal cause is the fact situation against this right (causa petendi).

When the plaintiff asks the court to its final decision to restore his rights violated, must first prove that there is a state that has delayed and violated his right. This state of fact plaintiff must prove with evidence. In Article 154 of the Code of Civil Procedure has determined that the petition should contain narrative of facts, circumstances, documents and other evidentiary materials.

Showing of facts and circumstances is an element that must contain a claim to be considered complete. "Presentation of the facts is important because even contradictory debates will take place between the parties about these facts and legal consequences and ultimately will be these facts object of the trial judge".1

The petition must be individualized, the individualization of the claim is important and the fact that the same issue can not be placed twice. According to the doctrine, there are two theories. "The first theory is that of individualism that defines the individualization of the claim, suffice some factual data that remove any doubt about the right of the plaintiff. The second theory is that of substanting which supports the idea that the claim should contain detail made all the factual information from which derives the right of the plaintiff ".2

The subject matter of the lawsuit is what is required as a result of filing suit (pettitium), implementation of the law and profit of what is required that comes from such law enforcement recognition of the right of ownership etc.. So with filing the claim in court made known to the court the object of dispute.

Supreme Court by Unifying Decision No. 9 dated 09.03.2006 stated that " Determination of the lawsuit, the claim in terms of section 154 of the Code of PR. The Civil corresponds to what is required to gain as a result of law enforcement, in terms of defining the object of the claim, provided for in Article 185 of the Civil Procedure Code ".

When talking about the subject of the lawsuit will understand that what is required to achieve the object of the plaintiff and not the material that is the object of the claim, provided as an element of its Code of Civil Procedure section 154. The object of the claim specified in section 154 of the Code of Civil Procedure is a material object that the plaintiff seeks.

Supreme Court with its decision no.1288, dated 19.11.2001 argues that "Only fair determination of the legal relationship to the conflict by determining the cause of the claim, the evidence of each party's obligations in relationships and fulfillment of these obligations in reality and review of all rebuttals will enable fair resolution of the matter."

Italian legislation is more flexible predicting that if the elements of the claim are not shown in the claim, but can be drawn from the content of the claim, then the claim is deemed complete. Italian legislation provides the term "invalidity" when the claim is not criterions elements provided for in Article 163 of the Code of Civil Procedure. It remains without action until these flaws are met. Has the same prediction French procedural law. 
There can be thought of a lawsuit without a subject that raises before the court and without a subject against which the claim arises. It is the subject, who by his wishes to exercise his right to sue in court and obtain a right that he thinks belongs. No subject had not induction of court motion.

In Article 90 of the Code of Civil Procedure stipulates that: "Parties to a civil trial are natural or legal persons, on behalf of or against whom judgment". So by this definition we conclude that both parties in a civil process: one party is a natural person or legal entity that requires the court to restore the law that is being violated, and the other party is a natural or legal person against whom judgment by convened to discuss the trial and to raise objections on the merits and the merits of the claim of the plaintiff law.. 1

Subject to the terms of the right to file suit in court or prosecutor called active subject and the subject to which the petition is directed called ignorant or passive subject. The plaintiff and defendant are called differently litigants.

Litispendence provided New Code of Civil Procedure section 161 under which "actions may be taken jointly by the many plaintiffs or against many defendants if:

a) Have common rights and obligations on the subject of the claim;

b) The rights and obligations in terms of fact or of law have the same basis. "

In the case where a plaintiff and a defendant in the case as well as the bashkëndërgjyqësisë to be a party to a civil procedural legal relationship must: have a party procedural legal capacity and procedural capacity to act.

That a person has the right to benefit from the protection offered by the state authorities for the realization of a right that is violated, the individual must have an interest in protecting this right.

Article 32 of the Civil Procedure Code provides for cases when a person may be sued. In the first paragraph of this article reads as follows:

Lawsuit may be filed:

*To seek the restoration of a right or legitimate interest is violated;

Plaintiff to be legally justified for asking and recognition of a right as well as for the restoration of a right and for the restoration of a right infringed or denied must be the person that according the law was violated or denied this right (active legitimacy).

The plaintiff's interest as well as the defendant should be. :

Legitimate and lawful interest

Legitimate interest has to do with the fact that the plaintiff may exercise the right to sue only when it is infringing, denied or violated a right that has been infringed, denied or violated a right that he is recognized by law. This is exactly provided in the first paragraph of Article 32 of the Code of Civil Procedure.

Legal interest:

Legal interest can be moral and pecuniary. In the current civil procedural legislation does not exist a provision to determine whether the right can be exercised lawsuit when the plaintiff the value of request is very small. Well enough to have an interest, however small it be, and the person can legally exercise claim..

Direct and personal interest:

Only the one person who is deprived of, infringed and violated the right has the right to sue for its restoration. Nobody can petition the court to attaining respect and protect the rights of someone else.

Since the legitimate claim as entirely legitimate components must meet the above mentioned investment at the time of the court..

\section{CONCLUSION}

At the conclusion of this paper would like to draw your attention once again to the most its important moments.

${ }^{1}$ Neni 154 I K.Pr.Civile "Kërkesëpadia duhet të përmbajë përcaktimin e objektit të kërkespadi 
The lawsuit is one of the oldest institutions of civil procedural law and one of the main means for restoration of the subjective right. Lawsuit in legal doctrine is treated in both material and procedural terms, civil lawsuit in material terms is the faculty or legal powers of a person to seek the realization of a civil right against another person, regardless of if it is against the will of his own, while in the procedural terms is the faculty or legal power to ask the court for recognition or restoration of a right denied or infringed by a another person, who is regularly called before the courts, ie civil lawsuit in the procedural terms is a mean of protecting the right through the court. The lawsuit consists of three elements which are the subject matter, the legal cause and parties.

The lawsuit during the trial may change as the subject of legal cause, but it can not change the two elements simultaneously. Besides the theoretical treatment of the lawsuit and its elements judicial jurisprudence of the Supreme Court provides answers to many discussions that exist for the lawsuit in general and in particular its elements. The lawsuit as a procedural remedy, to propel the court for review of a lawsuit should contain the elements set forth in section 154 of the Code of Civil Procedure otherwise, the lawsuit will be returned from the court for deficiency. It is important to note that the court should be careful when analyzing a lawsuit, if it meets all the elements. Court should analyze in detail if these elements are met. The Court finds that even when one of these elements is not fully defined, but that can be drawn from the content of the lawsuit, shall not reverse the lawsuit for deficiency. Civil Procedure Code has explicitly defined the elements that seem to contain a claim and the court may not enlarge the circle of those requirements. It is recommended that the court should be careful when analyzing a lawsuit, should not extend the circle of those requirements established by law. So, for example it should not reverse the lawsuit for default when it determines that litigation is not fairly regulated, because the litigation of the parties is related to the interest of them in a trial which is due to acceptance or to reject the lawsuit and not to reverse the lawsuit.

For this reason it is recommended that adjustments be made to the above being explicitly defined that how much would be a lawsuit tax for all objects of lawsuits.

It is recommended that in the future the lawmaker to regulate by law the issue of whether during the trial in the Court of Appeal, the respondent may file a new impeachment he had not filed during the trial in the Court of First Instance.

In conclusion I would like to emphasize the lawsuit as well as procedural protective means of the respondent are provided to guarantee the rights of persons, protection of their subjective rights.

\section{B I B L I O G R A P H Y}

Ottoman Civil Procedure and Civil Procedure Appendix

Second Appendix to the Code of Civil Procedure. year 1929

Law number 275 dated 13.08.1946 "On the judicial organization

Ordinance of the Minister of Justice no. 2579 dated 10.31.1946 "On some procedural norms"

Law No. 2625 dated 17.03.1958 Code of Civil Procedure;

Law No. 6341 dated 27.06.1981 Code of Civil Procedure of 1981;

Law No. 7574, dated 24.06.1992 "On the organization of the justice system and some changes in the codes of civil and criminal procedure '

Law nr.7689, dated 17.03.1993 "On some amendments to Law 7574, dated 24.06.1992" On the organization of the justice system and some changes in the codes of civil and criminal procedure;

Law nr.7742, dated 26.07.1993 "On Amending Article 213 of the Code of Civil Procedure;

Law nr.7806, dated 03/17/1994: On Amendments to the Law 7574 dated 24.06.1992 "On the organization of the justice system and some changes in the codes of civil and criminal procedure;

Law No, 7919, dated 04.19.1995 "On amending the Law 7574, dated 24.06.1992" On the organization of the justice system and some changes in the codes of civil and criminal procedure;

Law nr.7922, dated 19.04.1995 "On an amendment to the Code of the Republic of Albania, amended by Law nr.7537, dated 17.12.1991" On some amendments to the Civil Procedure Code of the Republic of Albania "; 
Nr.8116 Law dated 29.03.1996 Code of Civil Procedure of 1996, as amended by Laws nr.8431 dated 02.14.1998, nr.8491 dated 27.05.1999; No.8335 dated 18.10.199; nr. 8812 dated 17.05.2001;

Constitution of 8417 dated 21.10.1998;

The Civil Code of Albania Republika approved by Law 7850 dated 29.07.1994;

The Family Code of the Republic of Albania approved by Law 9062 dated 08.05.2003;

Law No. .8977, dated 12.12.2002 "On the tax system in the Republic of Albania";

Law for Kosovo Procedure;

Italian Code of Civil Procedure

Alqiviadh Lamani Civil Procedure of the People's Republic of Albania. Tirana 1962

Prof. Dr Faik Brestovci. Civil Procedural Law. Pristine 2006;

Civil Procedure (lectures).). Flutura Tafaj .Dr.Vitore Tusha. Edition 2003 Tirana;

Roman Law Prof.Asoc.Dr. Arta Mandro. Emal 2007

Comparative Overview on Civil Procedure.. Alessandro Simoni, Sokol Sadushi, Sokol Como Tirana 2006 ;

nternational Civil Procedure Law Prof.Dr. Faik Brestovci

Princippi di dirintto Processuale Civile ,Giussepe Chiovenda,Jovene Editore. Napoli

II nuovo cidice di procedura civile illustrato con la giurisprudenza ed il commento dottrinale.Francesko Bartolini/

Ilprocesso ordinario di cognizione,Elio Fazzalari.

Parties in civil process, Lessons for Teaching, School of Magistrates. Av.Dashamir Kore .

Digesto delle discipline Privatistiche IX ,Sezione Civile .

Documento e documentazioni .Pierluigi Milite .

The Albanian dictionary today. Academy of Sciences of Albania. Institute of Linguistics and Literature., Toena publishing house, Year 2002.

Unifying Decision No.09 dated 09.03.2006 of the High Court

Decision No. 1288 dated 19.11.2001, the Civil Division of the High Court

Decision No. 308 dated 30.11.2007, the Civil Division of the High Court

Decision No.1581 dated 20.03.2007, Tirana District Court

Decision No. 8588 dated 30.11.2007, Tirana District Court

Decision No. 188 dated 12.01.1996-The Court of Cassation Italy

http://www.studiocelentano.it

http://www.ligjet.org

http://en.ëikipedia.org/ëiki/Expert_witness

http://www.gijkataelartë.com

http://www.gijkatatirana.com

http:www.revistagiuridica.it 